му транснациональных корпораций, обладающих передовыми ресурсосберегающими, наукоемкими, технологичными процессами производства и добычи. В дальнейшем при внедрении указанных технологий и обучении отечественных кадров осуществляется вытеснение данных иностранных компаний с национального рынка и из добывающей отрасли. Хотя применить перечисленные инструменты государственной промышленной политики удалось пока только КНР [7, с. 14].

Российская Федерация, к сожалению, не в полной мере использует широко распространенные инструменты защиты национальных интересов в развитии горно-добывающей промышленности. Основная причина такой ситуации - устранение государства от регулирования данной отрасли. Все крупнейшие месторождения платиноидов находятся в разработке частных компаний, в том числе с иностранным участием. В итоге роль государства сведена к организации и обеспечению работы механизма вывоза полезных ископаемых за пределы Российской Федерации, а не к созданию высокотехнологичных производств внутри страны, ограничению вывоза невозобновляемых полезных ископаемых за пределы национальной территории, созданию внутреннего спроса на добываемую величину платиноидов.

1. Петров, И.Ф. Глобализация и унификация потребления // Современные гуманитарные исследования. 2020. - № 4 (95). - С. 26-28.

2. Васильева, А.В. Группировка регионов Российской Федерации по уровню устойчивого развития экономики // Проблемы и перспективы развития экономики и менеджмента в России и за рубежом: Материалы XII Междунар. научно-практ. конф. 19-20 ноября 2020 г. - Рубцовск: Рубцовский индустриальный ин-т, 2020. C. $94-102$.

3. Ступникова, А.В. Теоретические аспекты формирования и функционирования локальных рынков // Проблемы современной экономики. - 2013. - № 2 (46). - С.70-72.

4. Кочубей, Е.И., Сапунов, А.В. Факторы дестабилизации экономики России в 2020 г. и механизмы их предотвращения // Естественно-гуманитарные исследования. - 2021. - № 34 (2). - С.108-112.

5. Рыбакова, Л.В., Истомин, В.С. Математическое моделирование экономической эффективности управленческих решений в условиях современного предприятия // Современные проблемы экономики и управления: состояние и перспективы. Материалы II национальной конф. - 2016. - С. 23-29.

6. Мясоедов, С.А. Экономика и право: монография. - Чебоксары: ИД «Среда», 2021. - С.55-71.

7. Мясоедов, С.А. Анализ процесса формирования концепции устойчивого развития экономических отношений // Экономические науки. - 2016. - № 04 (137). - С.13-17.

УДК $553.411(571.6)$

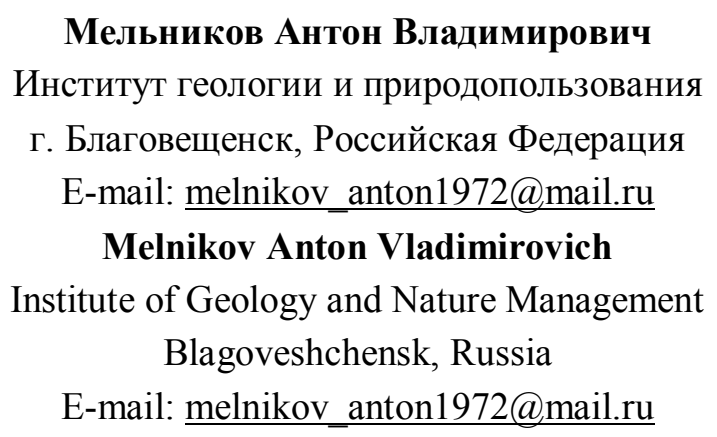

Степанов Виталий Алексеевич

Научно-исследовательский геотехнологический центр ДВО РАН

г. Петропавловск-Камчатский, Российская Федерация

E-mail: vitstepanov@yandex.ru

Stepanov Vitaly Alekseevich

Geotechnological Research Center of the Far Eastern Branch

of the Russian Academy of Sciences

Petropavlovsk-Kamchatsky, Russia

E-mail: vitstepanov@yandex.ru 
БАМСКОЕ ЗОЛОТОРУДНОЕ МЕСТОРОЖДЕНИЕ ПРИАМУРЬЯ: ИСТОРИЯ ОТКРЫТИЯ И ИЗУЧЕНИЯ (ДАЛЬНИЙ ВОСТОК, РОССИЯ)

\section{BAMSKY GOLD DEPOSIT IN THE AMUR REGION: HISTORY OF DISCOVERY AND STUDY (FAR EAST, RUSSIA)}

Аннотация. Бамское золоторудное месторождение Приамурской провинции открыто в 1979 2. при проведении литогеохимической съемки маситаба 1:200000. Поисково-оценочными и разведочными работами установлен крупный масштаб месторождения. Приводится обзор публикаций по его геолого-структурным особенностям, геохимии и минеральному составу руд. Указывается, что Бамское месторождение может быть основой золотодобывающей промышленности Амурской области на ближайшие десятилетия.

Abstract. The materials on discovery and study of the Bamskoye gold deposit of the Amur province are given. The field was discovered in 1979 during lithogeochemical survey of 1: 200000 scale. The carried out prospecting and exploration work established a large scale of the field. An overview of publications on geological and structural features of the deposit, geochemistry and mineral composition of ores was made. It is indicated that the Bamskoye deposit may be the basis of the gold mining industry of the Amur Region for the coming decades.

Ключевые слова: золоторудное месторождение, золотодобывающая промышленность, минералогия, геохимия.

Key words: gold deposit, gold mining industry, mineralogy, geochemistry.

DOI: 10.22250/jasu.95.21

Золоторудное месторождение «Бамское» расположено в северо-западной части Амурской области, в верховьях р. Чульбангро. Оно приурочено к Бамскому рудному узлу Северо-Становой металлогенической зоны Приамурской провинции [11]. «Бамское» замыкает тройку крупных золоторудных месторождений Приамурья, открытых в 70-е гг. ХХ в.: «Покровское»- 1975 г., «Пионер»1978 г. и «Бамское» - 1979 г. По сравнению с указанными месторождениями освоение «Бамского» значительно затянулось. Так, месторождение «Покровское» к настоящему времени полностью отработано. С 1999 г. на нем добыто около 63 т золота. Добыча на месторождении «Пионер» началась немного позже - в 2004 г. К настоящему времени извлечено около 76 т золота, освоение его продолжается. Попытка извлечь золото из руд месторождения «Бамское» в 2000-2001 гг. принесла всего 0.5 т металла. История открытия и изучения месторождения в значительной мере объясняет отставание в его освоении.

Как уже отмечено, месторождение «Бамское» открыто в 1979 г. при проведении литогеохимической съемки масштаба 1:200000 партией № 3 ПГО «Центргеофизика» во главе с начальником партии В.В. Домчаком (В.В. Домчак и др., 1981 ф). Первое название месторождения - «Чульбангро», по названию небольшой речки в районе месторождения. Затем оно было переименовано в «Бамское» из-за близости к Байкало-Амурской ж.д.

В 1981-1989 гг. на месторождении были поставлены детальные поисковые работы с проходкой наземных горных выработок, сначала партией № 3 ПГО «Центргеофизика (В.В. Домчак и др., 1986 ф), а затем Апсаканским отрядом Благовещенской поисково-съемочной экспедицией (А.В. Ложников и др., 1989 ф). В результате выявлены в коренном залегании, прослежены по простиранию и опробованы первые золоторудные тела.

С 1990 г. по 1993 г. на месторождении проводились поисково-оценочные работы масштаба 1:10000 с проходкой канав и бурением скважин колонкового бурения сначала Тындинской ГРЭ ПГО «Таежгеология» (Л.П. Курник и др., 1991 ф), а затем Северо-Амурской геолого-разведочной экспеди- 
цией (Е.Д. Молчанов и др., 1995 ф). В результате установлены и оценены 17 рудных тел. Для 9 из них подсчитаны запасы золота и серебра по категории С2, а для остальных - прогнозные ресурсы категории Р1. Средняя протяженность рудных тел составила 790 м, средняя мощность - 2.3 м. Средние содержания золота и серебра соответственно 5.9 и 16.9 г/т. (Е.Д. Молчанов и др., 1995 ф).

Изучение вещественного состава руд и технологии их переработки произведено в СевероВосточном филиале ЦНИГРИ (В.А. Макеев и др., 1991 ф). По результатам фазового анализа установлено, что 94.2-96.2\% золота и 89.5-92.6\% серебра находятся в свободном состоянии. Предложены две схемы обогащения - гравитационно-флотационная и гравитационно-цианистая.

Согласно исследованиям (Н.И. Королев и др., 1991 ф), извлечение золота и серебра из руд месторождения «Бамское» возможно методами цианирования измельченной руды, кучного выщелачивания, а также гравитационно-флотационного обогащения. При этом выход золота составляет 65 96\%, серебра - 56- $85 \%$.

Результаты изучения структуры и закономерностей локализации рудных тел месторождения изложены в отчете АмурКНИИ ДВО РАН (В.А. Степанов и др., 1995 ф).

В 2000-2001 гг. на месторождении была предпринята попытка начать производство золота методом кучного выщелачивания (КВ). Производство оказалось недостаточно эффективным из-за невозможности селективной выемки окисленных руд. Вследствие этого в штабель было уложено значительное количество первичной (упорной для КВ) руды. В течение двух лет извлечение неуклонно снижалось, было получено всего 500 кг золота, средняя степень извлечения составила 50\% [3].

В 2005-2009 гг. ООО «Амурское ГРП», ФГУГП «Урангеологоразведка» и ЦФ «Горногеологическая экспедиция» производили доразведку Бамского месторождения с обоснованием ТЭО временных разведочных кондиций и подсчетом запасов (В.К. Белов и др., 2009г.). Согласно приказу ГКЗ № 2073 от 2009 г. запасы золота месторождения «Бамское» по категориям АВС1 составили 17376 кг, категории С2 - 90127 кг, при среднем содержании золота 4.1 г/т.

В сентябре 2014 г. Правительство РФ рекомендовало приступить к отработке месторождения «Бамское». Лицензию на геологическое изучение и добычу золота приобрела компания ООО «Амурское геолого-разведочное предприятие». После завершения строительства рудника планируется добывать не менее 3 т золота в год.

Первооткрывателями этого крупного месторождения признаны: В.В. Домчак, Н.В. Калабин, Л.П. Курник, С.В. Савенко (приказ Минприроды России № 546-ЛС от 24.07.2013 г.).

Сведения о результатах поисковых и оценочных работах на месторождении являются закрытыми, поэтому рассматриваются только материалы, опубликованные в открытой печати. Первые сведения о геологическом строении месторождения, закономерностях размещения рудных тел и составе руд опубликованы Л.П. Курником [5]. Отмечается, что руды месторождения мало- или умеренносульфидные, с массивной или брекчиевой текстурой. Основными рудными минералами являются пирит, халькопирит, галенит и золото, отмечаются блеклая руда, сфалерит, шеелит, гессит, матильдит, акантит и петцит. Золото мелкое и тонкое, проба его колеблется в широких пределах - от 629 до 961\%, в среднем 825\%. Отношение золота к серебру в рудах составляет 1:3.

В 1996 г. появилась статья о Бамском золоторудном узле [13]. На основании геолого-структурных геофизических и геоморфологических данных показано, что Бамским рудным узлом является вулкано-плутоническая структура центрального типа. Она сложена субвулканическими интрузиями и дайками раннего мела, а рамой служат гранитоиды Чубачинского массива раннего протерозоя, содержащие ксенолиты гнейсов и кристаллосланцев архея. В ее пределах находятся месторождение золота «Бамское», рудопроявления «Дес», «Ерничное» и «Сивали», а также проявление серебра «Ключ». Золотое и серебряное оруденение парагенетически связано с субвулканическим и дайковым комплексами раннемелового возраста. Внутри рудного узла выделены три рудных поля - Бамское, 
Ключевское и Десовское, которым отвечают секторные блоки вулкано-плутонического поднятия. В качестве рудоконтролирующей и рудоэкранирующей структуры Бамского месторождения выступает зона одноименного разлома полукольцевой формы. Мощность зоны около 300 м при протяженности 4 км. Рудные тела не выходят за пределы этой зоны. Они представлены кварц-карбонатными жилами и зонами прожилкования с вкрапленностью и гнездами сульфидов, а также субсогласными участками брекчирования и милонитизации.

Другое определение Бамского рудного поля дано в монографиях по золоторудным месторождениям Востока России [6] и по металлогении Приамурья [15]. Под рудным полем понимается линейный штокверк ВСВ простирания длиной 3 км и шириной 0.5 км. В его пределах выделяется ряд жилообразных параллельных залежей сложной формы, сочетающих прожилково-штокверковый и кварцевожильный типы оруденения. Рудные тела представляют собой минерализованные зоны дробления и брекчирования, пересекающие структуры вмещающих мигматитов архейского возраста. Отмечается, что рудное поле примыкает с юга к локальной гравитационной аномалии, являющейся фрагментом регионального минимума силы тяжести, располагается в аномальном поле калия и в нейтральном магнитном поле. Совмещение аномального поля калия с гравитационной аномалией указывает на местоположение массива гидротермалитов, генетически сопряженного на глубине с гранитоидной массой. Нейтральное магнитное поле района месторождения на фоне окружающего положительного поля обусловлено разрушением магнитных минералов в процессе минералообразования.

Руды малосульфидные с содержанием рудных минералов 3-5\%, иногда до 10\%. Они состоят из кварца, кальцита, анкерита и серицита с примесью флюорита, барита, калишпата, хлорита, мусковита. Кроме указанных в статье Л.П. Курника рудных минералов, добавлены сульфосоли, теллуриды, киноварь, полибазит, гематит, марказит и магнетит. Среднее содержание золота в рудных телах составляет 8.4 г/т, серебра - 24.8 г/т, содержание вольфрама $-0.01-0.8 \%$, меди $-0.02-3 \%$. Отмечается положительная корреляция золота с серебром, медью, вольфрамом и ртутью.

В публикации [8] приведено определение изотопного возраста руд месторождения «Бамское» и рудопроявления «Дес». Оно выполнено Rb-Sr-методом в отделе изотопной геологии ВСЕГЕИ, на приборе МИ-1201Т. Изучались мономинеральные фракции, главным образом мусковита и серицита, а также кальцита и флюорита, из коллекции В.А. Степанова. В результате получена изохрона $129 \pm 3.6$ млн. лет, свидетельствующая о раннемеловом возрасте золотого оруденения Бамского узла (рис. 1).

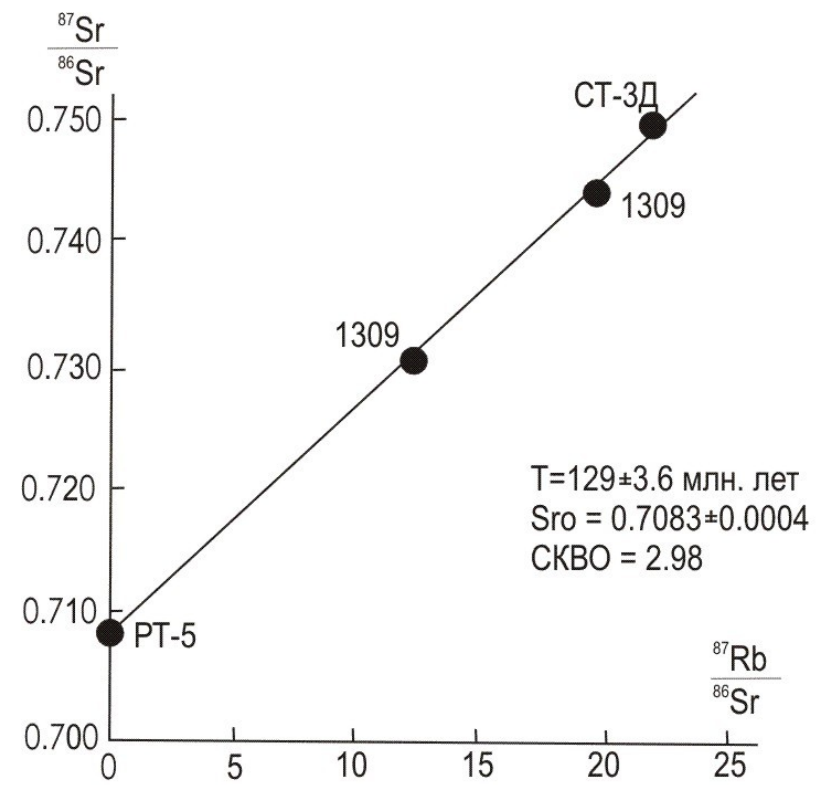

Puc. 1. Rb-Sr изохронный график для минералов руд

Бамского месторождения и рудопроявления «Дес» [8]. 
А.А. Даниловым изучались геохимическая характеристика и зональность золотого оруденения Бамского месторождения[4]. Установлено, что для золоторудных объектов Бамского рудного узла характерен единый типоморфный комплекс элементов, включающий $\mathrm{Au}, \mathrm{Ag}, \mathrm{Cu}, \mathrm{W}, \mathrm{Pb}, \mathrm{Bi}, \mathrm{Mo}$, $(\mathrm{Hg}, \mathrm{Sb})$. Для Бамского месторождения типоморфными элементами являются Au1113, W136, Ag61, Cu44, Mo39, Sb33, Bi24, Pb10, Zn9.

Кроме того, выявлено столбовое распределение золотосеребряной минерализации как на уровне всего месторождения, так и на уровне рудных тел. В размещении рудных столбов намечается горизонтальная зональность. В направлении с запада на восток по мере удаления от Невачанской субвулканической интрузии раннемелового возраста продуктивность рудных столбов и масштабы их проявления уменьшаются. На месторождении выявлена также горизонтальная и вертикальная зональность оруденения. Обобщенный ряд осевой зональности составляют (снизу вверх): Mo-W-Co-Ni$\mathrm{Pb}-\mathrm{Cu}-\mathrm{Au}-\mathrm{Bi}-\mathrm{Ag}-\mathrm{Zn}-\mathrm{Sb}-\mathrm{Ba}-\mathrm{Mn}$. Зональность рудного тела № 7, не выходящего на дневную поверхность, - на рис. 2.

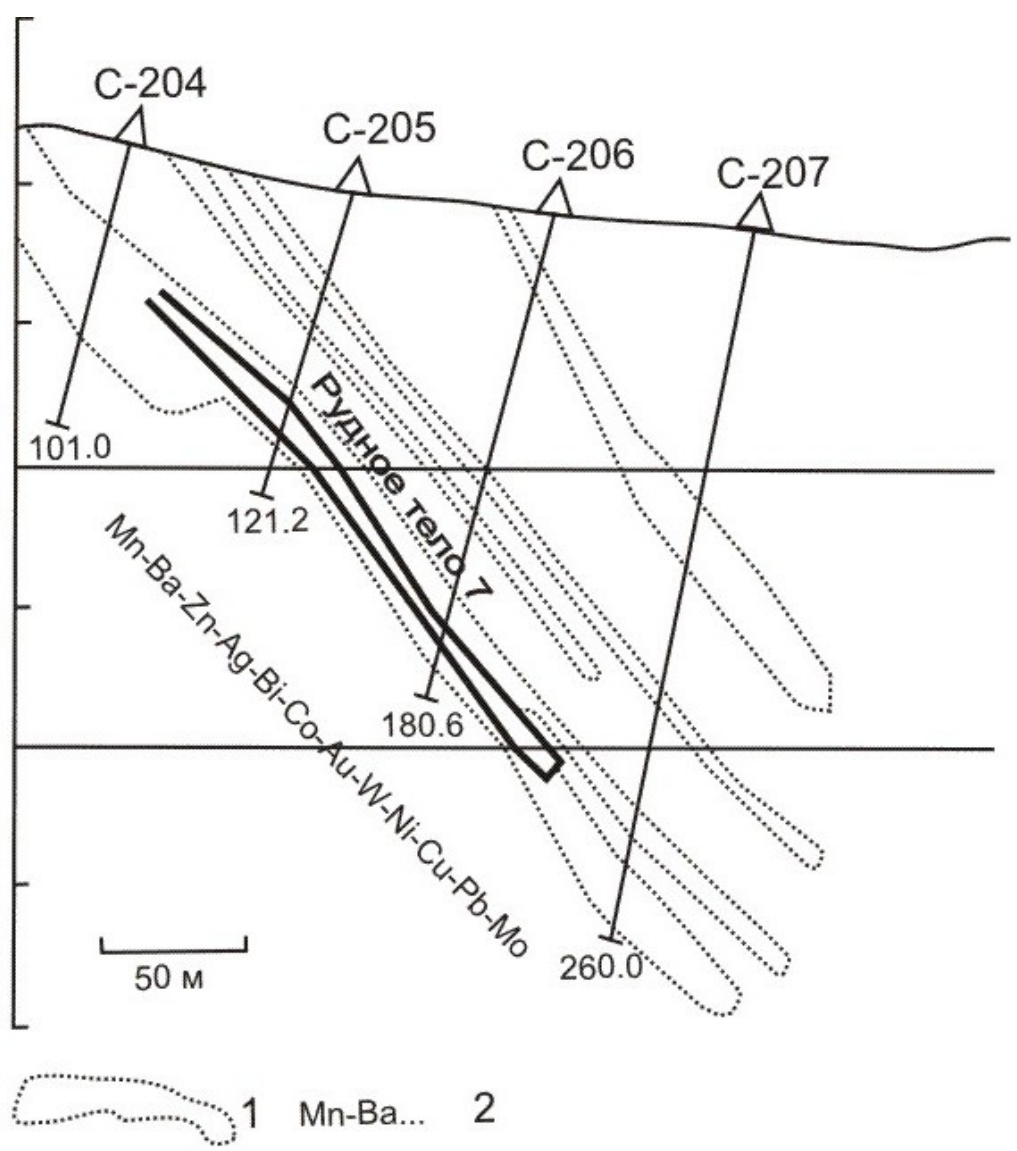

Puс. 2. Геохимическая зональность рудного тела № 7, не выходящего на дневную поверхность [4]: 1 - ореолы гидротермалитов; 2 - ряд зональности элементов-индикаторов.

Наиболее подробное описание месторождения «Бамское» приведено в коллективной монографии [1]. В первой части книги освещена региональная позиция месторождения в геологических структурах, геофизических и геохимических полях. Показана приуроченность месторождения к Бамскому рудному узлу Северо-Тукурингрской металлогенической зоны Приамурской золотоносной провинции. Установлено, что Бамскому узлу отвечает вулкано-плутоническое поднятие центрального типа, сложенное субвулканическими интрузиями и дайками раннемелового возраста, прорывающими докембрийский гранито-гнейсовый субстрат. Прогнозно-геохимические исследования позволили выделить геохимические поля в ранге рудного района, узла и рудного поля, а также дать их прогнозную оценку на золото, серебро и молибден. 
Во второй части книги приведено подробное описание геологического строения, структурной приуроченности золотого оруденения, минерального состава, геохимических особенностей руд и околорудных метасоматитов, а также изотопного возраста месторождения «Бамское». По мнению авторов, месторождение представляет собой систему золотоносных кварцевых, карбонатно-кварцевых жил и жильно-прожилковых зон, располагающихся в надинтрузивной части Невачанской интрузии сиенит-порфиров раннего мела Рудные тела приурочены к кулисно построенной системе разрывов, развитых в лежачем боку Бамского сброса, играющего роль экранирующей структуры (рис. 3,4$)$.

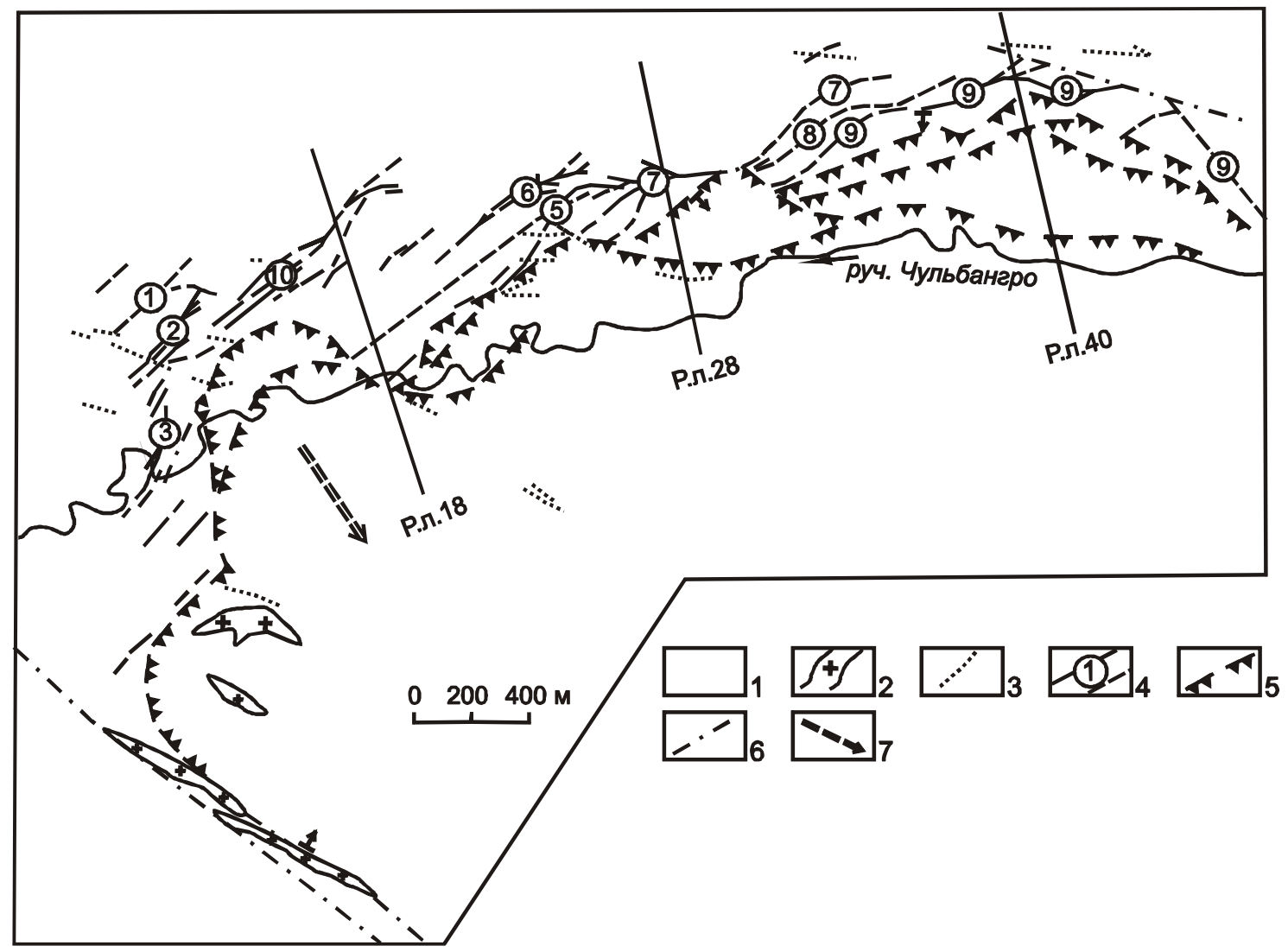

Puc. 3. Структурная схема Бамского месторождения [1]:

1 - гранито-гнейсы докембрия; 2 - кварцевые сиенит-порфиры Невачанского комплекса; 3 - дайки диоритовых порфиритов и лампрофиров раннего мела; 4 - рудные тела и их номера; 5 - плоскости сместителей зоны Бамского сброса; 6 - радиальный разлом; 7 - направление склонения осей синформных перегибов плоскости Бамского сброса.

В составе руд преобладают кварц, карбонаты и серицит. Среди рудных минералов, количество которых редко превышает 1-5\%, наиболее распространены пирит, халькопирит, галенит, шеелит и самородное золото. Менее развиты блеклые руды, теллуриды золота и серебра, сульфовисмутиды, сфалерит и киноварь. При минераграфическом описании руд выделено пять стадий минерализации. Наиболее продуктивной на золото является поздняя рудная золотосульфидно-сульфосольная стадия с теллуридами золота и серебра. Основная масса золота отлагалась совместно с сульфосолями и теллуридами из относительно низкотемпературных (250-180оС) гидротермальных растворов в близнейтральных слабощелочных условиях и слабоокислительной обстановке.

Для руд месторождения выявлен типоморфный ряд элементов: $\mathrm{Au}, \mathrm{Ag}, \mathrm{W}, \mathrm{Cu}, \mathrm{Bi}, \mathrm{Mo}, \mathrm{Pb}, \mathrm{Sb}$. Установлена латеральная и вертикальная геохимическая зональность оруденения. Вертикальный ряд зональности составляют (снизу вверх): (W1, Pb1, Mo)-Cu-(Ag, Bi, Sb, Mn, W2, Pb2). Вмещающие оруденение гранитоиды Чубачинского массива превращены в березиты, по ксенолитам кристаллосланцев развиты листвениты, менее проявлены процессы аргиллизации. Изотопный возраст золотого оруденения, определенный калий-аргоновым и рубидий-стронциевым методами по рудосопровождающим минералам, равен соответственно 109-129 и 130,6 млн. лет. На книгу имеется рецензия [14], в 
которой отмечается полезность монографического описания золоторудных месторождений ввиду ожидаемого перевода золотодобывающей промышленности России от россыпного на рудное сырье. По материалам книги опубликовано краткое сводное описание месторождения [12].
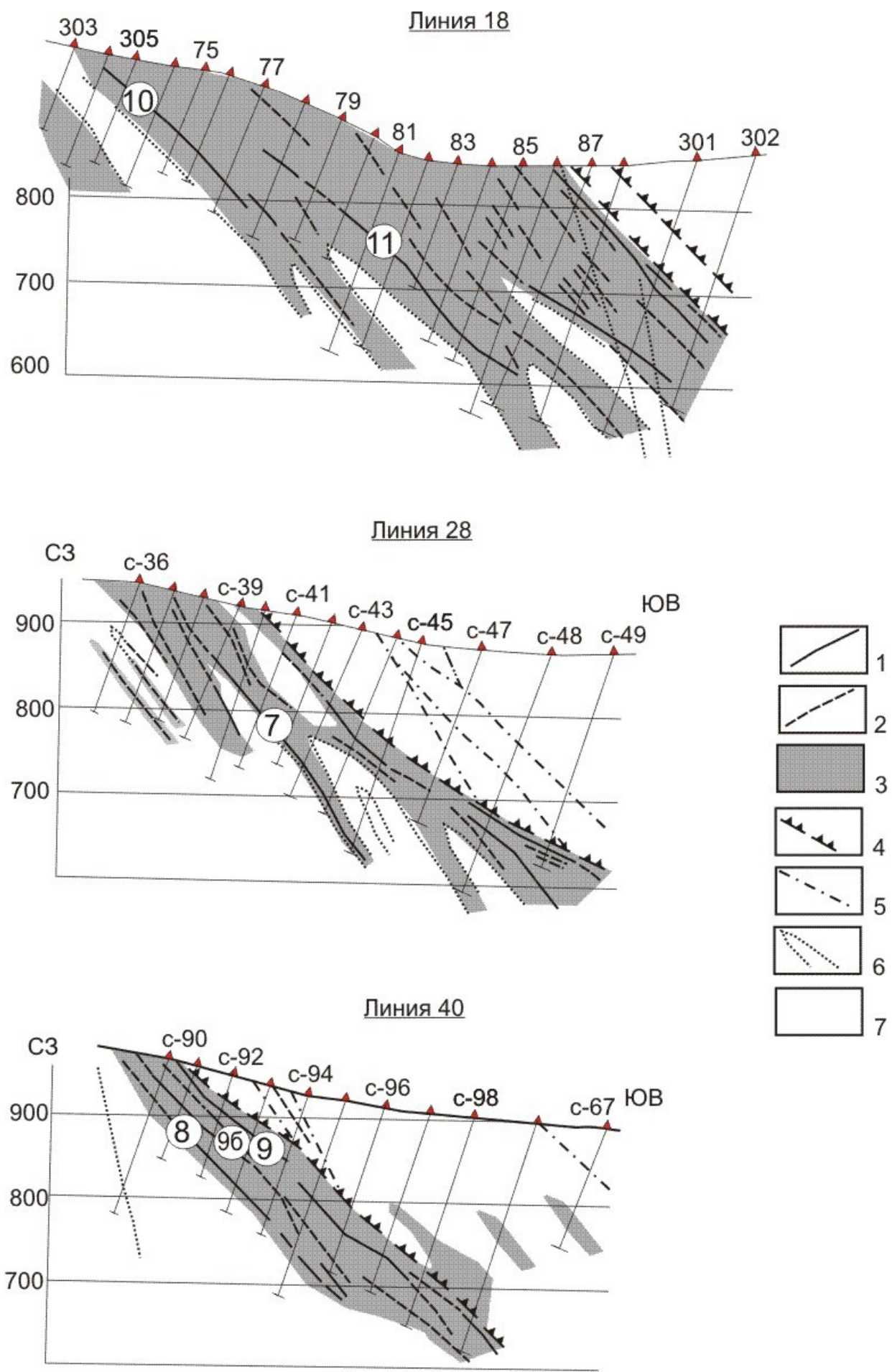

Puc. 4. Разрезы рудных тел Бамского месторождения по разведочным линиям [1]:

1-2 - рудные тела промышленные (1) и забалансовые (2); 3 - метасоматиты; 4 - плоскость сместителя Бамского сброса; 5 - прочие разломы; 6 - дайки диоритовых порфиритов и лампрофиров; 7 - гранито-гнейсы.

В книге «Минерально-сырьевая база Амурской области на рубеже веков» [7] дается краткое описание месторождения «Бамское». Оно отнесено к золотокварцевой формации. Главная роль в структуре месторождения отведена Чульбангринскому надвигу, в аллохтоне которого располагаются все рудные тела. Они представлены тремя морфологическими типами: зонами прожилкового и прожилково-сетчатого (штокверкоподобного) окварцевания; кварцевыми, реже кварц-карбонатными жи- 
лами с сульфидной минерализацией; минерализованными зонами дробления, рассланцевания и милонитизации, нередко с глинистыми швами. Мощность рудных тел колеблется от 0.7 до 22.4 м, в среднем 2.3 м. Протяженность - до 1500 м. Они прослежены скважинами до глубины 600 м, в среднем до 300 м. Средние содержания золота составляют 5.9 г/т, серебра - 16.9 г/т. Золото в основном свободное, от субмикроскопического до мелкого, преобладающие размеры золотин 0.2-0.6 мм. Средняя проба 780\%, при колебаниях от 556 до 961\%. Доля «сульфидного» золота не превышает 3.4\%. Отмечается, что по суммарным запасам и прогнозным ресурсам это одно из крупнейших золоторудных месторождений на юге Дальнего Востока.

В 2007 г. вышла. статья С.А. Григорова, посвященная геохимической характеристике Апсаканского (Бамского) рудного узла [2]. Показано, что аномальная структура геохимического поля почти правильно округлой формы по внутренней границе марганца, отражающей фронтальную зону концентрирования. Она в целом совпадает с контурами структуры центрального типа, отвечающей рудному узлу. Локальный ореол золота в самом центре ядра, совпадающий с Бамским месторождением, окружен по всему периметру фронтальной зоной концентрирования золота более высокого ранга. $\mathrm{B}$ ее пределах располагаются рудопроявления - сателлиты Бамского месторождения, имеющие подчиненное значение. В ядре системы расположено геохимическое поле свинца.

Геофизические характеристики Апсаканского рудного узла и месторождения «Бамское» подробно освещены в статье М.Ю. Носырева [10]. Геофизические поля и элементы глубинного строения рассмотрены на трех уровнях: для Апсаканского узла, для западной части узла, где расположено месторождение «Бамское», и, собственно, для месторождения. Месторождение локализовано в области пониженного электрического сопротивления, сопряженной с блоком высокого электрического сопротивления. Рудоносная зона вытягивается вдоль контрастной геоэлектрической границы, разделяющей два блока, различных по уровню электрического сопротивления пород, и следует за ней по простиранию и падению. Кроме того, рудоносная зона отмечается слабым повышением поляризуемости. Повышение поляризуемости связано с наличием сульфидов в рудах месторождения и вмещающих метасоматитах. Магнитное поле на площади, включающей месторождение, имеет сложный характер и к югу от него сильно дифференцировано. Месторождение в целом, включая рудные тела, минерализованные зоны и окружающие их гидротермалиты, отличается слабым понижением магнитного поля, интенсивностью в несколько десятков нТл.

В 2017 г. вышла статья Е.М. Некрасова и Т.Н. Косовец о возможном приросте ресурсов золота на трех месторождениях Дальнего Востока, в том числе «Бамском» [9]. Указывается, что рудные тела месторождения приурочены к пластине протерозойских и архейских гранитов, надвинутой по надвигу широтного простирания на основание гранитов раннего протерозоя. Оруденение заключено на отрезке надвига длиной 3 км, заключенного между двумя поперечными разломами северо-восточного простирания - Рудным и Длинным (рис. 5).

К востоку от «Длинного» и к западу от «Рудного» разведкой могут быть обнаружены новые рудные тела. В связи с эрозией верхней кромки надвинутой пластины рудные тела, вероятно, будут обнаруживаться к востоку от руч. Длинного на все большей глубине.

Обзор материалов по золоторудному месторождению «Бамское» позволил сделать следующие выводы:

«Бамское» является одним из наиболее крупных золоторудных месторождений Приамурья. Запасы его превышают 100 т золота, при среднем содержании золота 4.1 г/т. Руды мало- и умеренносульфидные. Доля свободного легко извлекаемого золота составляет более 90\%. Основные добываемые компоненты - золото и серебро, попутные - медь и вольфрам. Месторождение может быть основой золотодобывающей промышленности Амурской области на ближайшие десятилетия;

начало эксплуатации месторождения в 2000-2001 гг. методом кучного выщелачивания оказалось неудачным из-за нарушения технологии извлечения золота; 
значительный срок между открытием месторождения (1979 г.) и предполагаемым началом золотодобычи объясняется отсутствием в северной части Приамурья золоторудных горно-обогатительных комбинатов.

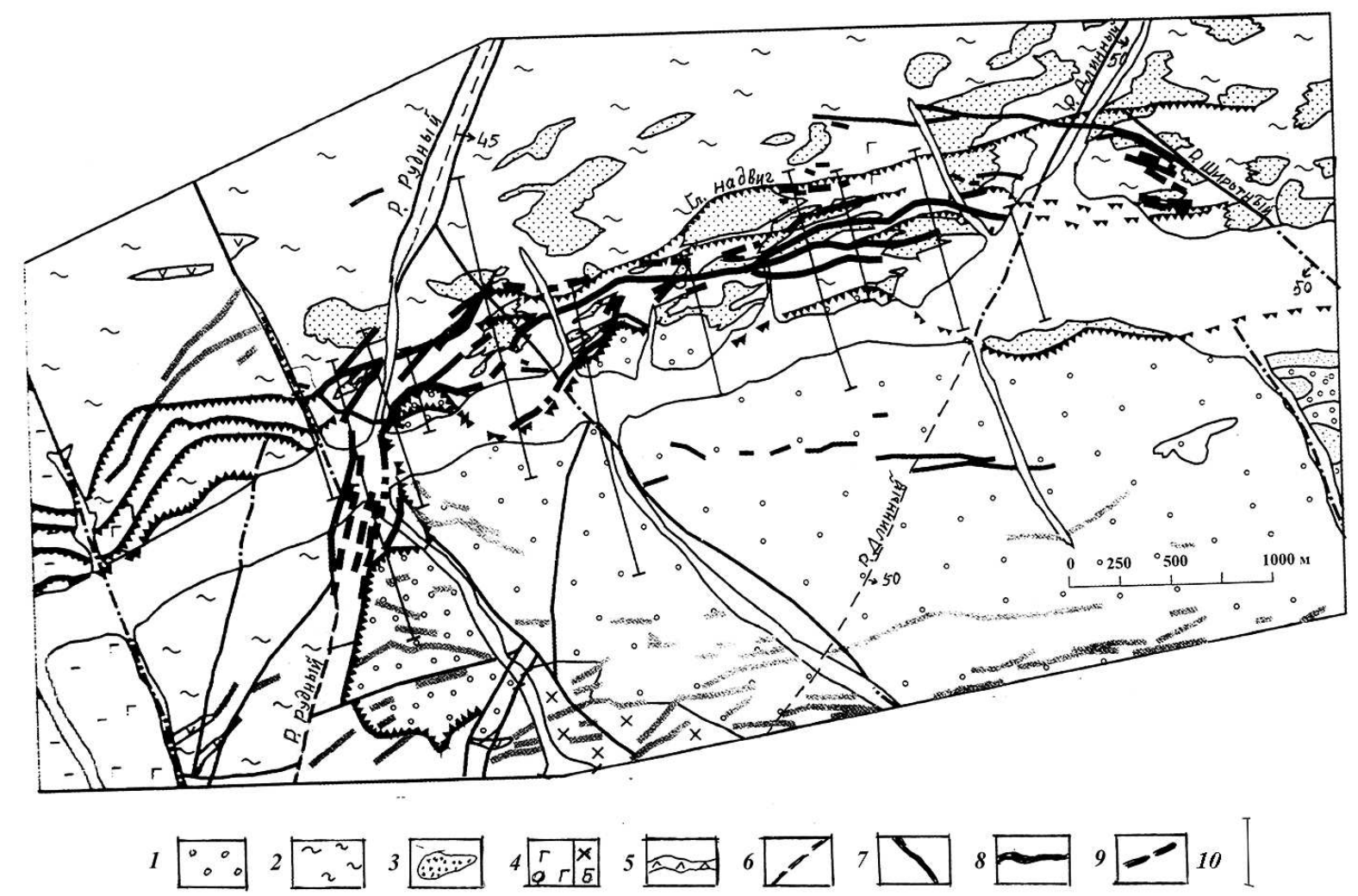

Puc. 5. Геологическая схема Бамского месторождения [9]:

1 - дорудные разломы: Р - Рудный, Длинный, Широтный, Гл. надвиг - Главный надвиг, 1 - гнейсовидные гранодиориты нижнего архея; 2 - граниты нижнего протерозоя; 3 - гнейсы верхнего архея; 4 - позднеюрские интрузии: а - гранодиорит- и граносиенит-порфиры, б - биотитовые граниты; 5 - дайки и субвулканические тела гранодиорит- и граносиенит-порфиров юрского возраста; 6 - рудоподводящие разломы; 7 - прочие разломы; 8-9 - рудные тела: а - выявленные, б - предполагаемые; 10 - буровые линии.

1. Бамское золоторудное месторождение (геология, минералогия и геохимия) / В.А. Степанов, В.Е. Стриха, А.А. Черемисин, Л.Я. Шмураева, А.А. Данилов, Н.В. Котов, Л.Г. Порицкая, М.С. Порицкий, С.В. Соколов. Владивосток: Дальнаука, 1998. - 208 с.

2. Григоров, С.А. Основы структурной интерпретации геохимических полей и столбов Бамского месторождения Приамурья // Отечественная геология. - 2007. - № 4. - С. 45-52.

3. Гудков, С.С., Дружина, Г.Я., Татаринов, А.П. Итоги технологии кучного выщелачивания в золотодобывающей промышленности России // Золотодобыча. - 2006. - № 88. - С. 7-11.

4. Данилов, А.А. Геохимическая характеристика и зональность золотого оруденения Бамского месторождения Приамурья: Автореф. дис. ... канд. геол.-минер. наук. - Благовещенск: АмурКНИИ, 1998. - 24 с.

5. Курник, Л.П. Некоторые геологические особенности нового золоторудного месторождения «Бамское» // Труды Ассоциации геологических организаций ДВ. - Хабаровск, 1992. - Вып. 2. - С. 93-99.

6. Минерально-сырьевая база Амурской области на рубеже веков / под ред. И.А. Васильева. - Благовещенск: КПР Амурской области, 2000. - 168 с.

7. Моисеенко, В.Г., Эйриш, Л.В. Золоторудные месторождения Востока России. - Владивосток: Дальнаука, 1986. $-352 \mathrm{c}$.

8. Моисеенко, В.Г., Степанов, В.А., Шергина, Ю.П. Возраст золотого оруденения Бамского рудного узла // ДАН. - 1997. - Т. 355, № 3. - С. 369-371.

9. Некрасов, Е.М., Косовец, Т.Н. Возможный рост ресурсов золота на трех отечественных месторождениях - Бамском, Многовершинном и Ольче // Известия вузов. Геология и разведка. -2017 . - № 6. - С. 73-79.

10. Носырев, М.Ю. Геофизические характеристики Бамского золоторудного месторождения (Верхнее Приамурье) и их использование при прогнозировании и поисках месторождений золота // Тихоокеанская геология. - 2016. - № 6. - С. 73-79. 
11. Степанов, В.А. Мельников, А.В., Вах, А.С. и др. Приамурская золоторудная провинция. - Благовещенск: Амурский гос. ун-т, 2008. - 232 с.

12. Степанов, В.А. Бамское золоторудное месторождение // Геология рудных месторождений. - 2001. T. 43, № 1. - С. 38-51.

13. Степанов, В.А., Черемисин, А.А. Бамский золоторудный узел Приамурья // Руды и металлы. - 1996. № 1. - С. 64-72.

14. Эйриш, Л.В. О книге «Бамское золоторудное месторождение» // Тихоокеанкая геология. - 2001. - № 2. C. 101 .

15. Эйриш, Л.В. Металлогения золота Приамурья (Амурская область, Россия). - Владивосток: Дальнаука, 2002. -193 c. 